\title{
Kadar Kolesterol dan Kualitas Telur Itik Lokal Menggunakan Tangkai dan Daun Talas Liar dalam Ransum
}

\section{The Cholesterol Content and Eggs Production that used Colocasia esculenta (L.) Schott in Local Duck Diet}

\author{
Zasmeli Suhaemi ${ }^{1}$ dan PN Jefri ${ }^{1}$ \\ 'Program Studi Peternakan, Fakultas Pertanian, Universitas Tamansiswa Padang. \\ Email:emizasmeli@gmail.com
}

$\begin{array}{ll}\text { Diterima } & : \text { 31 Januari } 2019 \\ \text { Disetujui } & : \text { 10 Februari } 2019 \\ \text { Diterbitkan } & : 21 \text { Februari } 2019\end{array}$

Abstrak: $\quad$ Produk ternak dengan kandungan rendah Kolesterol, akan meningkatkan kualitas produk tersebut. Penelitian ini bertujuan untuk melihat manfaat penggunaan talas liar sebagai salah satu bahan ransum, terhadap produksi telur itik lokal dan kandungan kolesterol darah dan telur. Sebagai perlakuan adalah level penggunaan Tepung Tangkai dan Daun Talas (TTDT) sebanyak 5 level (o\%; 5\%; 10\%; 15\% dan 20\%). Rancangan yang digunakan adalah Rancangan Acak Lengkap dengan 4 kali ulangan. Perlakuan diberikan kepada 8o ekor itik masa bertelur umur 19 minggu hingga 27 minggu. Hasil penelitian menunjukkan bahwa makin meningkat pemberian TTDT, akan meningkatkan berat telur, produksi telur dan menurunkan konversi ransum $(P<0,01)$ sampai level $10 \%$. Demikian juga dengan kandungan total kolesterol darah dan kuning telur nyata berkurang $(P<0,05)$, sampai level $20 \%$. Penggunaan TTDT sampai level $10 \%$ dapat meningkatkan berat dan produksi telur, dan penggunaan sampai level 20\% menurunkan kandungan kolesterol darah dan kuning telur, guna menciptakan sumber bahan pangan hewani yang rendah kolesterol.

Kata Kunci: Itik lokal, Kolesterol, Sumatera Barat, Talas liar.

Abstract: The product of livestock that has low cholesterol could increase the products quality. The study has purpose to observe the benefit of using the Colocasia esculenta leaves meal (TTDT) as an ingredient in diet towards the contents of local duck egg production and cholesterol. The treatment are using 5 levels TTDT (o\%; 5\%; 10\%; 15\%; and 20\%). All data were analyzed by Completely Random Design with 4 replication. This treatment given to 80 ducks that rare from 19 until 27 weeks. The result shown that the increasing of TTDT level up to $10 \%$ can increase the egg weight, egg production and decreasing of feed conversion $(P<0.01)$. The content of cholesterol of blood and yolk also significantly decreased $(P<0.05)$. The conclution of this research that using TTDT up to $10 \%$ could increase the egg production quality and created the source of low-cholesterol foodstuffs.

Keywords: Colocasia esculenta, local duck, egg production, cholesterol.

\section{Pendahuluan}

Secara umum beternak itik secara komersial, membutuhkan kandungan gizi ransum yang cukup serta pemberian pakan tambahan. Keunggulan itik lokal adalah kemampuan bertahan di lingkungan yang buruk serta penyakit dibandingkan dengan ayam, juga dalam memanfaatkan pakan dengan kualitas rendah, sehingga biaya pakan dapat berkurang. Produksi Itik lokal juga tergantung kemampuannya secara alami atau genetik.

Ransum merupakan yang paling penting dalam bidang peternakan, karena meliputi $70 \%$ dari total biaya produksi [1]. Sedangkan konversi ransum merupakan ukuran koefisien efisiensi teknis sering kali digunakan terutama pada eksperimen pengembangan produksi ternak unggas.

Salah satu produksi unggas adalah telur, yaitu sel telur (ovum) yang tumbuh dari sel induk (oogonium) di dalam indung telur (ovarium), dan oleh ternak unggas disediakan untuk bahan makanan bagi pertumbuhan embrio [2]. Telur menjadi pusat perhatian oleh masyarakat karena kaya akan nutrisi dengan harga yang relatif murah. Penilaian produktivitas telur dari sekelompok itik adalah dengan menghitung produksi harian atau PTH (Produksi Telur Harian). Produktivitas telur baik bila nilai PTH tersebut lebih dari $60 \%$. Itik mempunyai nilai PTH tinggi bila dipelihara tidak lebih dari umur 18 bulan. 
Kendala terbesar masyarakat dalam mengkonsumsi telur itik adalah kekhawatiran akan kandungan kolesterolnya yang tinggi. Kolesterol merupakan lipid amfipatik yang penting dalam pengaturan permeabilitas dan fluiditas membran, dan juga sebagai lapisan luar lipoprotein plasma [3]. Lipid terdiri dari trigliserida (lemak netral), fosfolipid (lecithin), dan kolesterol [4]. Namun tingginya kadar kolesterol itik lokal sering menjadi faktor pembatas bagi konsumen untuk berhati-hati dalam mengkonsumsi produk itik lokal. Kolesterol dalam tubuh yang berlebihan akan tertimbun di dalam dinding pembuluh darah dan menimbulkan suatu kondisi yang disebut aterosklerosis dimana terjadi penyempitan pembuluh darah. Kondisi ini merupakan cikal bakal terjadinya penyakit jantung dan stroke pada konsumen yang mengkonsumsi daging ayam tersebut [5].

Salah satu solusi untuk menurunkan kandungan kolesterol produk itik adalah tangkai dan daun talas. Tangkai pada daun talas mengandung zat yang bernama saponin, yang dapat menyingkirkan kolesterol dan sebagai antiseptik. Daun talas mengandung protein, karbohidrat, lemak, kalsium, fosfor, zat besi. Pada daun talas juga mengandung vitamin $\mathrm{A}, \mathrm{B} 1$, dan $\mathrm{C}$ dan daun talas juga memiliki zat polifenol yang berfungsi sebagai penangkal radikal bebas yang merusak sel-sel pada tubuh. Daun talas juga merupakan obat menahun yang mengandung flavonoid dan saponin yang berfungsi sebagai anti bakteri [6].

Daun talas merupakan tanaman yang memiliki banyak manfaat bagi kesehatan, yakni sebagai antihipertensi, antidiabetes, antimikroba dan analgesik [7]. Daun talas mengandung berbagai senyawa metabolit sekunder. Diketahui bahwa ekstrak daun talas mengandung komponen gula, polifenol, terpenoid, saponin, alkaloid, glikosida, steroid atau triterpenes, antrakuinon dan kumarin tanpa sianogenik. Namun hanya tanin, glikosida dan saponin tanpa flavonoid yang dapat diperoleh dari akar dan batang kulit daun talas. Selain itu, senyawa fenolik yang telah diidentifikasi dalam daun talas ialah golongan flavonoid. Ditambahkan bahwa daun talas terbukti mengandung antioksidan yang tinggi, dan berbagai zat bioaktif yang akan meningkatkan kesehatan [7].

Penelitian yang menggunakan daun talas pada tikus, terbukti mampu menurunkan kandungan lipid, kandungan kolesterol, trigliserida, K-HDL dan K-LDL [8]. Hal ini menunjukkan bahwa tanaman Talas diduga mampu menurunkan kandungan kolesterol produk itik lokal, sehingga menghilangkan faktor pembatas bagi masyarakat yang ingin mengkonsumsi daging itik lokal.

Penelitian ini bertujuan untuk menguji penggunaan tangkai dan tepung daun Talas dalam ransum itik lokal terhadap produksi telur, dan kandungan kolesterol darah dan telur itik lokal.

\section{Materi dan Metode}

Penelitian ini menggunakan itik lokal sebanyak 8o ekor umur 19 minggu sampai 27 minggu, yang dipelihara pada kandang sistem battery. Penggunaan tangkai dan daun Talas dilakukan dalam bentuk tepung. Tanaman talas yang sudah cukup lebar di cacah sepanjang $1 \mathrm{~cm}$, kemudian dijemur di bawah sinar matahari hingga kering dan mudah dihancurkan, kemudian digiling hingga halus dan diayak dengan ukuran mash ayakan $1 \mathrm{~mm}$.

Bahan ransum yang digunakan tercantum pada Tabel 1, dengan susunan ransum penelitian seperti tercantum pada Tabel 2. Ransum diberikan dengan jumlah yang sama yaitu $150 \mathrm{~g} / \mathrm{e} / \mathrm{h}$.

Tabel 1. Kandungan zat- zat makanan bahan-bahan ransum

\begin{tabular}{|c|c|c|c|c|c|}
\hline Zat Makanan & $\begin{array}{l}\text { Tepung } \\
\text { Keong** }^{*}\end{array}$ & Dedak Halus* & Jagung Giling* & Konsentrat* & TTDT $^{*}$ \\
\hline Bahan kering (\%) & 87,37 & 90,70 & 91,29 & 89,63 & 73,00 \\
\hline Protein kasar (\%) & 41,06 & 12,04 & 8,60 & 34,00 & 4,10 \\
\hline Serat kasar (\%) & 18,78 & 12,00 & 2,70 & 5,00 & 12,30 \\
\hline Lemak kasar (\%) & 1,30 & 1,70 & 4,20 & 3,00 & 2,10 \\
\hline ME (kkal/kg) & 2600,00 & 1630,00 & 3420,00 & 2600,00 & 71,00 \\
\hline Kalsium (\%) & 10,14 & 0,20 & $1, \mathrm{OO}$ & 12,00 & 0,30 \\
\hline Phospor (\%) & 0,49 & 1,00 & 2,56 & 1,20 & 0,04 \\
\hline
\end{tabular}

Ket : TTDT (Tepung Tangkai dan Daun Talas)

Sumber : : *Uji labor gizi unggas, (2009); **Uji labor gizi unggas, (2014) 
Tabel 2. Komposisi dan kandungan zat- zat makanan ransum penelitian

\begin{tabular}{|c|c|c|c|c|c|}
\hline \multirow{2}{*}{ Uraian } & \multicolumn{5}{|c|}{ Perlakuan } \\
\hline & $\mathbf{P 1}_{1}$ & $\mathbf{P 2}$ & $\mathbf{P}_{3}$ & $\mathbf{P}_{4}$ & $\mathbf{P}_{5}$ \\
\hline Jagung giling (\%) & 56,50 & 56,50 & 57,50 & 57,00 & 58,00 \\
\hline Dedak halus (\%) & 12,50 & 12,00 & 10,50 & 11,00 & 9,0o \\
\hline Bungkil kedelai (\%) & 21,00 & 20,50 & 21,00 & 19,00 & 20,50 \\
\hline Tepung ikan (\%) & 10,00 & 10,50 & 10,00 & 11,50 & 10,00 \\
\hline TTDT (\%) & 0,00 & 5,00 & 10,00 & 15,00 & 20,00 \\
\hline ME (kkal/kg) & 2645,38 & 2683,66 & 2606,04 & 2604,73 & 2583,04 \\
\hline Protein kasar (\%) & 17,03 & 17,06 & 16,90 & 17,13 & 17,53 \\
\hline Lemak kasar (\%) & 2,93 & 3,11 & 3,13 & 3,26 & 3,13 \\
\hline Serat kasar (\%) & 5,72 & 5,08 & 5,07 & 4,62 & 4,83 \\
\hline Ca $(\%)$ & 3,45 & 3,82 & 3,94 & 4,35 & 4,28 \\
\hline $\mathrm{P}(\%)$ & 1,65 & 1,68 & 1,63 & 1,63 & 1,48 \\
\hline
\end{tabular}

Dihitung berdasarkan Tabel 1.

Rancangan yang digunakan adalah RAL (Rancangan Acak Lengkap) dengan 5 perlakuan penggunaan tepung tangkai dan daun Talas (o\%; $5 \%$; 10\%; 15\%; dan 20\%), setiap perlakuan diulang 4 kali. Hasil analisis yang signifikan dilanjutkan dengan uji Perbandingan Berganda Dunkan.

Total Kolesterol (TK) darah, diperoleh dari serum darah itik yang diambil memalui pembuluh darah vena di vena pectoralis sebanyak $1 \mathrm{ml}$. Sedangkan TK kuning telur diperoleh dari hasil ekstrak kuning telur menggunakan etanol dan aseton teknis. Analisis TK, menggunakan Microlab 300 Spektrofotometer.

Variabel yang dianalisis pada penelitian ini adalah performa produksi telur itik dan TK darah dan kuning telur.

\section{Hasil dan Pembahasan}

Hasil penelitian terhadap berat telur, produksi telur, dan konversi ransum seperti yang tertera pada Tabel 3 .

Tabel 3. Rataan Berat telur, Produksi Telur, dan Konversi ransum

\begin{tabular}{rccc}
\hline Perlakuan & $\begin{array}{c}\text { Berat telur } \\
(\mathbf{g})\end{array}$ & $\begin{array}{c}\text { Produksi } \\
\text { Telur }(\%)\end{array}$ & $\begin{array}{c}\text { Konversi } \\
\text { ransum }\end{array}$ \\
\hline 0\% TTDT & $56,5^{\mathrm{a}}$ & $69,65^{\mathrm{ab}}$ & $4,15^{\mathrm{b}}$ \\
$5 \%$ TTDT & $55,76^{\mathrm{a}}$ & $73,81^{\mathrm{ab}}$ & $4,25^{\mathrm{ab}}$ \\
$10 \%$ TTDT & $64,12^{\mathrm{b}}$ & $75,92^{\mathrm{a}}$ & $3,92^{\mathrm{b}}$ \\
$15 \%$ TTDT & $60,76^{\mathrm{c}}$ & $67,45^{\mathrm{ab}}$ & $4,66^{\mathrm{a}}$ \\
$20 \%$ TTDT & $54, \mathrm{O0}^{\mathrm{a}}$ & $63,69^{\mathrm{b}}$ & $4,73^{\mathrm{a}}$ \\
\hline
\end{tabular}

Superskrip yang berbeda pada kolom yang sama menunjukkan berbeda nyata $(\mathrm{P}<0,05)$

Rataan berat dan produksi telur menunjukkan bahwa semakin meningkat penggunaan TTDT dalam ransum sampai level 10\% maka akan meningkatkan produksi, namun menurun pada penggunaan $15 \%$ dan 20\%. Penggunaan tepung daun Talas, juga terbukti nyata menurunkan konversi ransum itik lokal sampai level 10\%. Hal ini dapat disebabkan adanya kandungan anti nutrisi seperti halnya tanin, antosianin dan saponin dalam TTDT. Dilaporkan bahwa ekstrak etanol daun talas memiliki kandungan fenolik, antosianin, tanin, saponin, terpenoid, antrakuinon, alkaloid, flavonoid, sterol, karbohidrat, vitamin A dan C [9].

Hasil analisis ragam dari berat telur, produksi dan konversi ransum didapatkan hasil yang berbeda nyata $(\mathrm{P}<0,05)$. Hal ini disebabkan karena daun Talas diketahui mengandung zat-zat bioaktif dan antioksidan [7], sehingga dapat meningkatkan kesehatan ternak dan meningkatkan produksi serta lebih efisien dalam memanfaatkan pakannya, namun pada level $15 \%$ terjadi penurunan berat dan produksi telur, serta peningkatan konversi ransum.

Tabel 4 merupakan hasil analisis TK darah dan kuning telur itik lokal berdasarkan perlakuan penelitian.

Hasil Tabel 4 menggambarkan bahwa semakin meningkat penggunaan tepung daun Talas dalam ransum, maka akan menurunkan rataan TK darah $(\mathrm{P}<\mathrm{0}, \mathrm{o1})$, meskipun meningkat kembali pada level $15 \%$ namun tidak berbeda nyata $(\mathrm{P}>0,05)$ antara level 10\% sampai 20\%. Demikian juga halnya dengan kandungan Kolesterol kuning telur juga sangat nyata makin menurun $(\mathrm{P}<\mathrm{o.01})$, seiring dengan peningkatan penggunaan tepung daun Talas, namun hasil uji Perbandingan Berganda Dunkan menunjukkan tidak berbeda nyata $(\mathrm{P}>0,05)$ antara penggunaan TTDT $5 \%$ sampai $20 \%$

Tabel 4. Kandungan total kolesterol (TK) darah serta telur itik

\begin{tabular}{rcc}
\hline Perlakuan & $\begin{array}{c}\text { TK darah } \\
(\mathbf{m l} / \mathbf{d l})\end{array}$ & $\begin{array}{c}\text { TK yolk } \\
(\mathbf{m g} / \mathbf{1 0 0 g})\end{array}$ \\
\hline 0\% TTDT & $163,10^{\mathrm{a}}$ & $211,06^{\mathrm{a}}$ \\
$5 \%$ TTDT & $163,10^{\mathrm{a}}$ & $138,50^{\mathrm{b}}$ \\
$10 \%$ TTDT & $135,23^{\mathrm{b}}$ & $137,78^{\mathrm{b}}$ \\
$15 \%$ TTDT & $139,20^{\mathrm{b}}$ & $135,36^{\mathrm{b}}$ \\
$20 \%$ TTDT & $138,30^{\mathrm{b}}$ & $130,18^{\mathrm{b}}$ \\
\hline
\end{tabular}

Superskrip yang berbeda pada kolom yang sama menunjukkan berbeda sangat nyata $(\mathrm{P}<\mathrm{O}, \mathrm{O} 1)$

Hal ini menunjukkan bahwa penggunaan tepung daun Talas memiliki peluang untuk menghasilkan 
produk itik rendah kolesterol karena adanya zat saponin yang berfungsi untuk menurunkan kolesterol. Tangkai pada daun talas mengandung zat yang bernama saponin, yang dapat menyingkirkan kolesterol dan sebagai antiseptik [6]. Daun Talas mengandung berbagai senyawa metabolit sekunder. Diketahui bahwa ekstrak daun Talas mengandung komponen gula, polifenol, terpenoid, saponin, alkaloid, glikosida, steroid [10].

\section{Kesimpulan}

Penggunaan tepung dari tangkai daun Talas dalam ransum itik lokal, dapat meningkatkan produksi telur dan menurunkan konversi ransum sampai level $10 \%$, serta menurunkan kandungan total kolesterol darah, dan telur.

\section{Referensi}

[1] V. Pal, M. Gobade, K. Kanth, A. Thakur, and S. Maini, "Comparative Efficacy of Supplementation of Herbal Liver Tonic Products on Growth and Performance in Broilers," Int. J. Adv. Sci. Tech. Res., vol. 6, no. 7, 2013.

[2] T. Kurtini, K. Nova, and D. Septinova, Produksi Ternak Unggas. Bandar Lampung: Anugrah Utama Raharja (AURA) Universitas Lampung, 2011.

[3] K. M. Botham and P. A. Mayes, Harper's Illustrated Biochemistry: Cholesterol Synthesis, Transport \& Excretion. Amerika Serikat: McGraw Hill., 2012.

[4] K. C. Garaha, Kolesterol. Jakarta: PT Elex Media Komputido, 2010.

[5] H. Ma, "Cholesterol and Human Health," J. Am. Sci., vol. 2, no. 1, pp. 46-50, 2006.

[6] N. Khairany, N. Idiawati, and M. A. Wibowo, "Analisis Sifat Fisik dan Kimia Gel Esktrak Etanol Daun Talas (Colocasia esculenta (L.) Schott)," JKK, vol. 4, no. 2, pp. 81-88, 2015.

[7] S. K. Yeap et al., "Ethnomedical Used Green Vegetable with Multiple Bio- Activities," J. Med. Plants Res., vol. 4, no. 25, pp. 2787-2812, 2010.

[8] O. A. Adaramoye, O. Akintayo, J. Achem, and M. A. Fafunso, "Lipid-lowering effects of methanolic extract of Vernonia amygdalina leaves in rats fed on high cholesterol diet.," Vasc. Health Risk Manag., vol. 4, no. 1, pp. 235-41, 2008.

[9] N. Kumawat, S. Chaudari, N. Wani, T. Deshmukh, and V. Patil, "Antidiabetic Activity of Ethanol Extract of Colocasi esculenta Leaves in Alloxan Induced Diabetic Rats.," Int. J. PharmTech Reasearch, vol. 2, no. 2, pp. 12461249.

[10] N. Biren, B. Nayak, S. Bhatt, S. Jalalpure, and A. Seth, "The Anti-Inflamatory Activity of The Leaves of Colocasia esculenta," SPJ, vol. 15, p. 34., 2007. 